\title{
9
}

\section{The 2019 Energy Security Doctrine and Debates around It in Russia}

\author{
Tatiana Romanova
}

On 13 May 2019, the President of Russia approved a new energy security doctrine (ESD). This is the first such doctrine that Moscow has published (the previous two were either released as drafts or only summarised by their authors and by the Ministry of Energy). The publication of the doctrine is the result of dramatic changes in the international arena, which Russian neo-revisionist politics have provoked since 2014. To quote the secretary of Russia's Security Council Nikolay Patruchev, 'serious changes have occurred both in the world and in our country, new challenges and threats have emerged, and we could not but react to them'. ${ }^{1}$ These changes increased the West's concern about dependence on Russian hydrocarbons and led to sanctions against Russia that included restrictions on the supply of technologies for oil exploration and access to long-term finance, which in turn have affected long-term prospects for the development of Russian oil.

\footnotetext{
1 N. Patrushev, 'Patrushev: Odobrena novaya doktrina energeticheskoi bezopasnosti' [Patrushev: A new energy security doctrine is approved], Rossiiskaya gazeta, 29 November 2018.
} 
Visionary documents (i.e. concepts, strategies and doctrines) abound in Russia, although their legal status remains uncertain. ${ }^{2}$ Such documents tend to pursue at least three goals. First, they set policy priorities. In this case, the very preparation of the text and accompanying debates are of crucial importance. Second, they outline a program of actions in a particular field. These two types of documents can remain confidential, as they represent the steps that policymakers and bureaucracies might follow. The third goal of visionary documents is to outline the position for partners and outsiders. This is when publication of the final text becomes important, as demonstrated in the case of the 2019 ESD.

Preparation of the 2019 ESD was fairly secretive. Prior to its publication, the only official mention of it came from the Security Council in December 2017 (when the need to adopt a new doctrine was recognised) and in November 2018 (when the draft was approved). Predictably, the Security Council was central to its preparation. Any debate about the preparation of the 2019 ESD (if it took place) was not made public. Yet, we can discern a number of controversial or debate-worthy issues in the ESD from the documents to which it refers (or does not refer), from general discussion about points covered in the ESD and from reaction to the ESD. Three groups of issues can be identified: geopolitical/market paradigms, energy mix, and geography and diversification. After describing the historical context relevant to the ESD, I examine these issues, focusing on the nature of changes, their novelty and relevant debates among key stakeholders-the state, companies and experts.

\section{Historical Perspective on Russia's Energy Security Doctrines}

Russia's three ESDs were prepared by the Ministry of Energy and approved by the Security Council before being put in the form of a presidential decree. However, as mentioned above, neither the first nor the second

2 D. V. Iroshnichenko and S. V. Nesterov, 'Ponyatie i klassifikatsiya konteptualnyh i doktrinalnyh dokumentov Rossiiskoi Federatsii' [Concept and classification of conceptual and doctrinal documents of the Russian Federation], Pravovaya initsiativa 7 (2013), 49e.ru/ru/2013/7/7; M. A. Mushinsky, 'Strategii, kontsepsii, doctriny v pravovoi sisteme Rossiiskoi Federatsii: problemy statusa, uridicheskoi tehniki i sootnosheniya drug s drugom' [Strategies, concepts, doctrines in the legal system of the Russian federation: problems of status, legal techniques and correlation], Uridicheskie tehniki 9 (2015): 488-99. 
were published. Yet, their drafts were presented and both documents were explained by experts that took part in their elaboration and by the Ministry of Energy.

The first Russian ESD was prepared in December 1997 after nearly two years of debates among experts. ${ }^{3}$ A relatively short document, it defined energy security as a state that had to be achieved in the context of both external and internal threats. It emphasised economic and sociopolitical threats and paid little attention to external challenges. This approach seems logical given the overall political and international climate of the 1990s when Russia did its best to become a good (but also key) member of the international community and mostly concentrated on domestic reforms. This approach also mirrors the first (1992) Russian foreign policy concept.

The second ESD was adopted in November 2012 after two years of intense debate by experts. It was even more concise than the 1997 document. ${ }^{4}$ In defining 'energy security', it emphasised both the supply and demand of 'citizens, society, state, economy', thereby reflecting the importance of production and consumption. Building on advanced studies, it stressed resource availability, economic affordability, environmental sensitivity and technological achievability. ${ }^{5}$ Its definition of 'global energy security' underlined Russia's international ambition to be a 'global energy superpower' - a goal frequently attributed to Russian President Vladimir Putin.

Compared to the earlier document, the 2012 ESD included a more elaborate catalogue of threats. It started with internal economic threats (e.g. quality of energy reserves, quality of exploration and production equipment, and low level of investments) and sociopolitical threats (e.g. labour conflicts and terrorist attacks), but it also added technological (i.e. man-made) and natural threats. Finally, it reflected on external economic and political threats, which included insufficient geographical diversification (i.e. high share of European market in the export of Russian hydrocarbons), high politicisation of energy relations, instability

\footnotetext{
3 'Proekt doctrine energeticheskoi bezopasnosti' [A draft of energy security doctrine], Energeticheskaya politika 2 (1996): 2-7.

4 S. M. Senderov, 'Strategy obespecheniya energeticheskoi bezopasnosti Rossii' [Strategy for securing energy security for Russia], Proatom, 23 May 2013, www.proatom.ru/modules.php?name=News\& file $=$ article\&sid $=4532$.

5 V. V. Bushuev, N. I Voropay, S. M. Senderov and V. V. Saenko, 'O doctrine energeticheskoi bezopasnosti Rossii' [On Russia’s energy security doctrine], Ekonomika regiona 2 (2012): 40-50; B. K. Sovacool and I. Mukherjee, 'Conceptualizing and Measuring Energy Security: A Synthesized Approach', Energy 36 (2011) 5343-55, doi.org/10.1016/j.energy.2011.06.043.
} 
of global energy and financial markets, vulnerability of transit and limits on Russian companies' access to exploration worldwide. The 2012 ESD also introduced a system of regular monitoring for the purpose of energy security, which again mostly emphasised internal economic, technological and sociopolitical threats, thus fixing their primacy.

The 2012 ESD revealed an ambiguous attitude to energy saving and climate change. On the one hand, it stressed the importance of energy saving. Yet, on the other, it emphasised the negative influence of the climate on energy production and transportation (rather than the other way around) and pointed out that Russia might be forced to purchase unnecessary energy technologies under the cover of energy efficiency and the fight against climate change.

Like the first ESD, the 2012 doctrine reflected the mood at the time of its approval. By then, Russia had become more assertive and was seeking to use its abundant natural resources to achieve a more important role in the international arena. The document suggested that Russia might hold a different attitude on pertinent global issues and, in that sense, was similar to the foreign policy concept of 2013 .

The ESD released in 2019 is different from its 2012 predecessor in many respects. ${ }^{6}$ It makes early reference to the 2015 National Security Strategy and 2017 Economic Security Strategy, emphasising import substitution, but does not refer to the 2009 Energy Strategy ${ }^{7}$ until the end, thereby establishing its conceptual primacy. It contains fewer definitions than earlier iterations and notably omits a definition of global energy security, reflecting Russia's moderated international ambition. While a definition is provided for 'energy security', 'population' is offered as a substitute for 'citizens and society', reflecting a particularly Russian style of relations between the state and society.

The 2019 document contains a detailed section (8 out of 18 pages) on challenges, risks and threats. These are described in terms of a hierarchy, whereby challenges create stimuli and potential problems, risks exacerbate potentially dangerous issues and threats to energy security are the phenomena that have to be countered. Challenges, risks and threats are divided into three thematic subcategories: external economic, political and military;

6 President of Russia, Doktrina energeticheskoi bezopasnosti [Energy security doctrine], no. 216, 13 May 2019.

7 Pravitelstvo Rossiiskoi Federatsii, Energeticheskaya strategiya Rossii na period do 2030 goda [Energy strategy of the Russian Federation to 2030], no. 1715-p 13 November 2009. 
internal economic; and cross-border (terrorist, environmental) groups. In sharp contrast to the previous doctrines, this catalogue demonstrates the primacy of external factors over internal ones. Importantly, the interpretation of internal factors is different: while outdated equipment, insufficient exploration and the poor quality of labour resources are mentioned, incoherent development of the sector, excessive environmental demands and criminal activity in the energy sector are prioritised. This clear change in focus predetermines a bigger state involvement.

Like its predecessors, the 2019 ESD is a child of its time. It reflects Russia's decision in 2012 to concentrate on external policy rather than domestic reforms and the situation the country found itself in following the 2014 crisis in Ukraine and imposition of Western sanctions. To better understand these changes and the plurality of options that are currently available, the next sections dwell in more detail on the three groups of issues identified above: market economics vs geopolitics, energy mix and geographical diversification.

\section{Geopolitics Beats Market?}

The approach to energy relations referred to as 'geopolitics' is rooted in the neorealist tradition of international relations, which concentrates on power politics and the fight for survival with little regard for transnational relations. It is linked to traditional, statist forms of organisation. This paradigm views energy as a strategic commodity rather than an average good and is based on state involvement in the management and transportation of resources and all major energy deals. As there is substantial obscurity in state decision-making about the management of the sector, a particular approach is required. ${ }^{8}$ The geopolitical approach presupposes centralised, top-down decision-making, as well as a negative understanding of external dependence and the need to manage this dependence. ${ }^{9}$

8 A. Correljé and C. van der Linde, 'Energy Supply Security and Geopolitics: A European Perspective', Energy Policy 34 (2006): 532-43, doi.org/10.1016/j.enpol.2005.11.008; D. Finon and C. Locatelli, 'Russian and European Gas Interdependence: Could Contractual Trade Channel Geopolitics?', Energy Policy 36 (2008): 423-42, doi.org/10.1016/j.enpol.2007.08.038; S. Peters and K. Westphal, 'Global Energy Supply: Scale, Perception and the Return to Geopolitics', in International Handbook of Energy Security, ed. H. Dyer and M. J. Trombetta (Edward Elgar Publishing, 2013), 92-113, doi.org/10.433 7/9781781007907.00014; E. Stoddard, 'Reconsidering the Ontological Foundations of International Energy Affairs: Realist Geopolitics, Market Liberalism and a Politico-Economic Alternative', European Security 22, no. 4 (2013): 437-63, doi.org/10.1080/09662839.2013.775122.

9 T. Casier, 'The Rise of Energy to the Top of the EU-Russia Agenda: From Interdependence to Dependence?' Geopolitics 16, no. 3 (2011): 536-52, doi.org/10.1080/14650045.2011.520862. 
Conversely, a market approach to energy policy is based on a neoliberal vision of international relations-positive interdependence-and a neoclassical vision of markets, which can resolve all problems with supply and demand. ${ }^{10}$ This approach starts with the premise that energy is just a commodity like any other. Hence, markets are the most appropriate vehicle to manage it. In this approach, states are rule providers, insofar as they ensure transparent, universal rules and the work of legal instruments. ${ }^{11}$ This approach, which presupposes long-term cooperation rather than competition, is not territory-based, involves various transnational actors (e.g. companies and consumers) and leaves most of the solutions to the market.

Conventionally, Russia is depicted as being geared towards a geopolitical approach. However, some studies have challenged this assumption, identifying important market trends in Russian energy thinking. ${ }^{12}$

The 2009 Energy Strategy is ambiguous on the subject of markets. ${ }^{13}$ The creation of a market environment is one of its 'main vectors'; however, it also emphasises market mechanisms, institutions of open trade in energy resources, infrastructure for transportation of these resources and increases in domestic gas prices. At the same time, it prioritises budgetary efficiency of the sector-being the difference between what the state invests in the sector and its return in the form of taxes and revenues-as well as modernisation and stable institutional structures. The danger of reliance on imported technologies is also stressed. A new energy strategy drafted in 2017 preserved this emphasis on market principles and advocated the need to 'change the correlation between state regulation and market competition in favour of the later (liberalisation)'. ${ }^{14}$

10 Casier, 'The Rise of Energy to the Top'; Correljé and van der Linde, 'Energy Supply Security and Geopolitics'; Stoddard, 'Reconsidering the Ontological Foundations'.

11 J. Bielecki, 'Energy Security: Is the Wolf at the Door?', Quarterly Review of Economics and Finance 42, no. 2 (2002): 235-50, doi.org/10.1016/S1062-9769(02)00137-0; A. Goldthau and N. Sitter, 'A liberal Actor in a Realist World? The Commission and the External Dimension of the Single Market for Energy', Journal of European Public Policy 21, no. 10 (2014): 145-72, doi.org/10.1080/ 13501763.2014.912251; A. Goldthau and J. M. Witte, Global Energy Governance: The New Rules of the Game (Washington, DC: Brookings Press, 2010).

12 T. Romanova, 'Is Russian Energy Policy towards the EU Only about Geopolitics? The Case of the Third Liberalisation Package', Geopolitics 21, no. 4 (2016): 857-79, doi.org/10.1080/14650045. 2016.1155049; M. Siddi 'The Role of Power in EU-Russia Energy Relations: The Interplay between Markets and Geopolitics', Europe-Asia Studies 70, no. 10 (2018): 1552-71, doi.org/10.1080/096681 36.2018.1536925.

13 Pravitelstvo Rossiiskoi Federatsii, Energeticheskaya strategiya Rossii na period do 2030 goda.

14 Ministry of Energy, Proekt enoergostrategii Rossiiskoi Federatsii na period do 2035 goda [Draft energy strategy of the Russian Federation to 2035], 2017, accessed 14 August 2019, www.energystrategy.ru/ ab_ins/source/ES-2035_09_2015.pdf. 
The 2019 ESD does not openly reject market logics, though it significantly moderates previous timid attempts to apply market principles in Russia. It does this by emphasising the danger of incoherent development without active state interference. Rather than creating the conditions for businesses to act in this field, it stresses the state's need to perfect territorial energy structures and regulate energy prices in Russia. The need for greater state involvement stems from a set of newly identified threats: criminal activities, ranging from inappropriate use of budgetary sources and counterfeiting to corruption and shadow economy; and the activities of security services and other institutions of foreign states. The threat posed by criminal activities was flagged in the lead-up to the release of the 2019 ESD, so it was not unexpected. ${ }^{15}$ Nevertheless, it lays ground for an active state involvement, which is the essence of the geopolitical approach to energy.

The 2019 ESD bluntly underlines the need to:

Develop competition ... in the [Russian] internal market and to eliminate competition, which does not respond to the economic interests of Russia, among different types of Russian energy resources exported to the global energy markets. ${ }^{16}$

This is in relation to competition between Russian pipeline gas and liquefied natural gas (LNG). Further moderating the application of market principles, the 2019 ESD highlights the need for import substitution for various technologies and equipment as a consequence of Western sanctions, which have also contributed to an increased role of the state. The doctrine emphasises that the state has to create conditions to 'ensure technological independence of Russia's energy sector and its competitiveness'. ${ }^{17}$ While concerns about imported technologies were present in the 2012 ESD and 2009 Energy Strategy, they have become more salient because of sanctions. In 2017, the new energy strategy draft observed:

15 'Today, Astrakhan Hosted a Visiting Meeting of the Secretary of the Security Council of the Russian Federation in the Southern Federal District', Security Council of the Russian Federation, 5 May 2019, www.scrf.gov.ru/news/allnews/1074/. See also V. Putin, Zasedanie Soveta Bezopasnosti Rossiiskoi Federatsii, [Meeting of the security council of the Russian Federation] 29 November 2018, kremlin.ru/events/president/news/59262.

16 President of Russia, Doktrina energeticheskoi bezopasnosti.

17 President of Russia, Doktrina energeticheskoi bezopasnosti. 
[The] dependence of [the] Russian energy sector on foreign technologies, equipment, machinery and materials reached a critical level in some fields and thus created a threat to the energy security of Russia. ${ }^{18}$

This is understandable, given that Russia is as much as 60 per cent dependent on foreign technologies, according to some assessments. ${ }^{19}$ Therefore, the state has pledged to contribute to import substitution and to develop Russian industrial and scientific potential, not just to enhance its energy superpower status, but also, and more importantly, to guarantee its very energy security- that is, the stability of supply both internally and externally.

Despite those tendencies that clearly strengthen Russia's traditional geopolitical approach, market rhetoric is still very present in the 2019 ESD. According to the doctrine, the state has to regulate to ensure 'competitiveness' of the Russian energy sector. Sanctions are framed as a means of unfair competition rather than as a political instrument meant to signal disagreement with Russia's behaviour in the international arena (this is true of Russian political discourse at large) ${ }^{20}$ Hence, there is a clear interest to preserve the market agenda, not only as a cover but also as an acceptable explanation of the West's behaviour.

Debates around market vs geopolitics have not been that ardent in Russia. Some experts praised the document while others stated that it was unnecessary and that market competition should be promoted instead. ${ }^{21}$ Others claimed that the goal of market promotion was too declaratory and did not reflect the real situation. ${ }^{22}$ For their part, companies concentrated on the need to decrease tax burdens and to allow for more flexible prices internally. LNG producers challenged the need to have a coherent line

18 Ministry of Energy, Proekt enoergostrategii Rossiiskoi Federatsii na period do 2035 goda.

19 Novak cf. G. Starinskaya, 'Chto izmenilos v rossiiskom TEKe za vremya sanktsii' [What has changed in the Russian fuel and energy complex during the sanctions], Vedomosti, 19 December 2017, www.vedomosti.ru/business/articles/2017/12/19/745720-rossiiskom-teke.

20 See, for example, V. Putin, Zasedanie Soveta Bezopasnosti Rossiiskoi Federatsii, 29 November 2018.

21 Grivach, A. 'Expert otsenil doktrinu energeticheskoi bezopasnosti Rossii' [The expert assessed the doctrine of Russia’s energy security], IZ, 14 May 2019, iz.ru/877856/2019-05-14/ekspertotcenil-doktrinu-energeticheskoi-bezopasnosti-rossii. See also D. Chugunoff, 'Rossiiskii Neftegaz', Facebook Group, 16 May 2019, www.facebook.com/groups/437496816287290/?ref=bookmarks.

22 Marinchenko cf. E. Kravchenko, 'Putin podpisal novuu doktrinu energobezopasnosti' [Putin signed a new energy security doctrine. What is he preparing Russia for?], Forbes.ru, 14 May 2019, www. forbes.ru/biznes/376041-putin-podpisal-novuyu-doktrinu-energobezopasnosti-k-chemu-ona-gotovitrossiyu?fbclid=IwAR27NP0YlEowBy4Z5GqhZ-c6xHU4C7AKxne9d5QTSzdBWvJBUe5xAGr7Ftw. 
on the export of Russian resources, which would ultimately preserve the interests of Gazprom. ${ }^{23}$ Others complained that the 2019 ESD does not provide guidance on how companies should align their export interests. ${ }^{24}$

Reflecting ambiguity in the government's approach, the most controversial issue is probably import substitution. For example, Russia's minister of energy, although admitting the need to foster the development of Russian technologies, stressed that this did not detract from market principles. However, experts warn that this will likely mean an increase in price and duplication of existing technologies, in many cases, to a lower standard. In the meantime, industrialists are optimistic about their ability to reach a target of 70 per cent independence in technologies, and an import substitution lobby has emerged to compete for state resources. ${ }^{25}$

In sum, the 2019 ESD tipped the balance between markets and geopolitics in favour of the latter. While some experts challenge the prudence of this step, companies mostly agree with it. Some disagreement exists in the area of export coherence, but the most debated topic is import substitution. These trends are not new; instead, they reinforce existing and historical tendencies, such as Russia's unwillingness to introduce competition and its concern about technological dependence. However, the justification for a geopolitical approach is new in some respects (e.g. criminal activities in the field of energy, danger of import dependence and sanctions). Russia's framing of Western measures in economic rather than political terms is also noteworthy.

\section{Energy Mix}

The roots of present debates about energy mix lie in the concept of energy transition, which describes how the structure of primary energy resources changes over time. ${ }^{26}$ The current stage is linked to the increased

23 See, for example, Mihelson in V. Putin, Zasedanie Soveta Bezopasnosti Rossiiskoi Federatsii, 29 November 2018; 'NOVATEK ran across Europe to Gazprom', Kommersant, 5 August 2019, www.kommersant.ru/doc/4052442?utm_source=newspaper\&utm_medium=email\&utm_campaign =newsletter.

24 Ushkov cf. Kravchenko, 'Putin podpisal novuu doktrinu energobezopasnosti'.

25 G. Shmal, 'Ot importozamescheniya k importonezavisimosti' [From import-substitution to import-independence], Sfera neft i gaz 2, no. 70 (2019): 18-21.

26 V. Smil, Energy Transitions: History, Requirements, Prospects (Santa Barbara: Praeger, 2010); V. Smil, Energy and Civilization: A History (MIT Press, 2018); B. K. Sovacool, 'How Long Will It Take? Conceptualizing the Temporal Dynamics of Energy Transitions', Energy Research \& Social Science 13 (2016): 202-03, doi.org/10.1016/j.erss.2015.12.020. 
role of renewables; electricity and energy efficiency; the phasing out of nuclear energy and oil; and decentralised electricity systems, both in terms of generation and consumption. ${ }^{27}$ Energy transition is driven by technological developments and policy choices (e.g. climate agenda), and by the will of importing countries to increase their energy security through domestic actions, both in terms of supply and demand. ${ }^{28}$ Energy transition is important for Russia in two ways: in relation to the supply of internal market and the affect it has on exports. While both points are present in current debates, the second has been much more significant in the discussion that accompanied the 2019 ESD.

The 2009 Energy Strategy paid considerable attention to the structure of the Russian energy mix, concentrating on the need to enhance the use of coal (including clean technologies), reduce the internal consumption of gas, improve the structure of exports through the use of processed rather than primary energy goods and support the use of nuclear technologies. ${ }^{29}$ Renewable sources of energy were the last to be mentioned and their support was mostly declaratory. The 2017 energy strategy draft also recognises the need to develop renewables, but again mentions them towards the end of the list of priorities. ${ }^{30}$ Moreover, it stresses the need to diversify in the areas of oil and gas through the production and export of more processed energy goods and LNG.

There has been a decrease in global energy demand as well as a change in its structure as a result of moves towards energy efficiency, energy saving and new energy sources (including renewables and LNG). The 2019 ESD recognises this as an external economic challenge for Russian energy security. ${ }^{31}$ Moreover, the 2019 ESD takes notice of increased competition in global energy markets, which has intensified due to the entry of new suppliers. The doctrine also conceptualises the increased salience of climate

27 J. Trüby and H.-W. Schiffer, 'A Review of the German Energy Transition: Taking Stock, Looking Ahead, and Drawing Conclusions for the Middle East And North Africa', Energy Transitions, 2 (2018): 1-14, doi.org/10.1007/s41825-018-0010-2; C. Hager and C. H. Stefes, Germany's Energy Transition: A Comparative Perspective (New York: Palgrave Macmillan, 2016), doi.org/10.1057/9781-137-44288-8.

28 A. A. Makarov, T. A. Mitrova and V. A. Kulagin, Global and Russian Energy Outlook 2019 (Moscow: Institut energeticheskih issledovanii RAN, Skolkovo, 2019).

29 Pravitelstvo Rossiiskoi Federatsii, Energeticheskaya strategiya Rossii na period do 2030 goda.

30 Ministry of Energy, Proekt enoergostrategii Rossiiskoi Federatsii na period do 2035 goda.

31 'Assistant Secretary of the Security Council of the Russian Federation Alexander Abelin Told Reporters That the New Doctrine of Russia's Energy Security Will Help to Forestall New Threats in This Area', Security Council of the Russian Federation, 16 May 2019, www.scrf.gov.ru/news/ allnews/2593/. 
policy and transfer to green technologies as an external political challenges to Russia's energy security. According to the 2019 ESD, although Russia 'supports international efforts to prevent climate change', it 'considers [it] unacceptable to analyse climate change issues and environmental protection from a biased point of view and to infringe on the interests of states, producing energy resources'. ${ }^{32}$

The 2019 ESD's characterisation of the green energy agenda as 'a challenge' was ridiculed by experts. ${ }^{33}$ Yet, it is worth remembering that a 'challenge' is defined in the document as something that creates both problems and opportunities. This distinguishes the 2019 ESD from the 2012 ESD, which mostly treated the climate agenda as a threat and seemed not to notice renewables. Indeed, some experts claim that the 2019 ESD signifies a paradigmatic shift because renewables are now treated as a challenge. ${ }^{34}$ According to the head of Russian Greenpeace's energy program, it is the first official Russian document to take proper notice of changes in the energy sector, and to treat renewables seriously. ${ }^{35}$ This groundbreaking change is likely to foster the most debate in coming years.

The distinction between external economic and political challenges is curious when it comes to energy transition. While, for Russia, the former are associated only with increased competition, the latter are about policy decisions imposed globally, which are believed to be artificially disadvantaging Russian resources in the international market.

Surprisingly, the linked topicsofenergy mix and the external competitiveness of Russia's resources have emerged as most the contentious in the context of the 2019 ESD. The position of state officials and big energy companies has remained predictably sceptical, with Vladimir Putin recently repeating a set of notorious arguments against renewables (i.e. that they lead to the death of birds, the multiplication of worms and make human life uncomfortable due to the installation of large equipment). ${ }^{36}$ According to Russian Member of Parliament Pavel Zavalny, the 'availability and low

32 President of Russia, Doktrina energeticheskoi bezopasnosti.

33 D. Chugunoff, 'Rossiiskii Neftegaz', Facebook Group, 16 May 2019, www.facebook.com/groups/ 437496816287290/?ref=bookmarks; M. Korchemkin, 'Rossiiskii Neftegaz', Facebook Group, 15 May 2019, www.facebook.com/groups/437496816287290/?ref=bookmarks.

34 Ivanov cf. Kravchenko, 'Putin podpisal novuu doktrinu energobezopasnosti'.

35 cf. A. Komrakov, 'Doktrina krugovoi energeticheskoi bezopasnosti' [Energy security doctrine], Nezavisimaya gazeta, 14 May 2019.

36 E. Vavina, 'Putin Stood up for Birds and Worms Suffering from Renewable Energy', Vedomosti, 10 July 2019, www.vedomosti.ru/business/articles/2019/07/09/806215-putin-vstupilsya-za-ptits. 
prices for hydrocarbons as well as [the] geography of renewables make the development of the latter economically non-profitable'; their use, he argues, should be limited to that of supporting traditional means of energy, especially in remote regions. ${ }^{37}$

For the most part, big companies do not notice renewables. Igor Sechin, CEO of Rosneft, declared recently that reports 'of the oil death [are] an exaggeration', and that 'oil will remain the basis of global energy for 20-30 years to come'.$^{38}$ In his view, sanctions and other decisions of regulators only distort the free market. To the extent that the state and companies have shown increased interest in LNG, this has been about generating more flexibility in global markets, including Russia's diversification from traditional European markets to Asian ones (see below).

Generally speaking, energy experts have engaged in a more intensive exchange of views than state officials or big companies over the 2019 ESD. While many support the official position, their arguments vary greatly. Some insist that Russia should concentrate on economic development, for while support for clean energy is 'noble and fashionable', it is not profitable. ${ }^{39}$ Others describe hydrocarbons as the cheapest means of energy, and renewables as nothing but a political story, subsidised by traditional energy. ${ }^{40}$ Proponents of green energy argue that renewables and energy efficiency fail to get proper attention in Russia. Part of the problem is that the 2019 ESD sees items that might ensure progress in the global energy market as threats to Russian exports, and fails to see that Russia is drowning in outdated energy production..$^{41}$ Others stress that the ESD is based on the idea that all new things are invented to harm Russia. ${ }^{42}$ Tatiana Mitrova, while not referring directly to the ESD, argues that Russia does not pay sufficient attention to climate change, and that this reduces the possibility of new technological development.

37 'Pavel Zavalny Commented on Anatoly Chubais's Idea of Introducing a Carbon Tax', Duma, 13 June 2019, duma.gov.ru/news/45281/.

38 'Igor Sechin Made a Keynote Speech at the X Eurasian Economic Forum in Verona', Rosneft,

19 October 2017, www.rosneft.ru/press/news/item/188133/.

39 Bykov cf. Komrakov, 'Doktrina krugovoi energeticheskoi bezopasnosti'.

40 K. Simonov, 'Voprosy k ispolnitelyam' [Questions to the performers], IZ, 17 May 2019, iz.ru/ 878846/konstantin-simonov/voprosy-k-ispolniteliam.

41 Chugunoff, 'Rossiiskii Neftegaz'.

42 M. Korchemkin, 'Rossiiskii Neftegaz', Facebook Group, 15 May 2019. 
This attitude cannot and will not change global developments; instead, Russian budget receipts from the export of energy resources will most likely decrease, even though natural gas will preserve its position. ${ }^{43}$

In sum, while Russian policy preferences for traditional resources remains the same, debates around the 2019 ESD demonstrate a gradual shift in attitude towards renewables and clean energy at large. They have become much more central in Russian energy discussions and an increasing number of Russian specialists stress their role in the energy transition, which will have serious implications for Russian exports and budgetary receipts. Yet, the 2019 ESD and most officials treat renewables and clean energy as (unfair) competition and, in some cases, as external political challenges. Internally, debates about the need to promote clean energy choices remain modest.

\section{Geographical Diversification}

The third group of issues that are important in the 2019 ESD stem from the way it promotes diversification of energy markets. Geographical diversification is not a new topic. Analysts have talked about the EU's and Russia's race towards diversification since at least the turn of the century. ${ }^{44}$ The key rationale for diversification is grounded in the EU's liberalisation packages, which upset previous arrangements in EU-Russian trade in gas. Curiously, the EU's policy choices, which are rooted in market thinking, are conceptualised by Russia as political steps to decrease the share of Russian resources.

The need to enlarge the share of the Asian market (to balance the loss of European consumers of Russian oil and natural gas) has been present in Russia for quite some time. For example, the 2009 Energy Strategy stresses the need to diversify channels of transportation of Russian oil and gas to Europe to maintain the share in traditional markets and enhance the security of supply and to diversify to Asia. The latter is linked to

43 T. Mitrova, Y. Melnikov, D. Chugunoff and A. Glagoleva, Vodorodnaya ekonomika - put $k$ nizkouglerodnomu razvitiu (M: Skolkovo, 2019). See also A. Sobko, 'Rossiya prospala energoperehod: chto my poteryaem' [Russia slept through the energy transition: What will we lose], RIA Novosti, 21 July 2019, ria.ru/20190721/1556719899.html; Makarov, Mitrova and Kulagin, Prognoz razvitiya energetiki mira i Rossii.

44 A. Monaghan, 'Dilemmy energeticheskoi bezopasnosti' [Dilemmas of energy security], Pro et Contra, May-June 2016. 
the need to develop oil and gas resources and the economy of Russia's Asian territories. ${ }^{45} \mathrm{New}$ programs of exploration have been initiated and diversification strengthened through the construction of an oil pipeline-Eastern Siberia - Pacific Ocean (with a projected capacity of up to $80 \mathrm{mtoe}$ ) — a gas pipeline - the Power of Siberia (with an intended capacity of up to $38 \mathrm{bcm}$ ) —and through plans to build gas storage and cooperate in electricity generation with China. ${ }^{46}$

The 2012 ESD described insufficient geographical diversification of export markets as a threat to Russia's energy security. The 2017 updated energy strategy draft did not mention European markets at all (but underlined the need to preserve traditional markets). ${ }^{47}$ Instead, it set a diversified energy resources export structure with a much higher share of the Asia-Pacific region as a goal.

There is considerable continuity in the 2019 ESD in terms of thinking about geographical diversification. However, it puts some emphases differently. First, it frames the reduction of Russias share in traditional (European) markets, which is due to energy transition and restrictions that affect some Russian exports, as a threat to Russia's energy security (security of supplier). The document does not openly name European markets but clearly refers to the EU's policy choices. Second, the 2019 ESD develops an argument about the migration of the centre of global economic growth to the Asia-Pacific region' and treats this as a challenge (providing both opportunities and threats) that the Russian energy sector has to deal with. In itself, this economic argument is not new. ${ }^{48}$ Yet, it has become much more salient in the new doctrine.

At the same time, the political aspects of diversification that support Russia's vision of a polycentric world and provide for close cooperation with China to challenge the authority of the West are not mentioned. This absence or silence can be seen as supporting the dominant discourse, whereby Russia is conducting a purely economically grounded energy policy-unlike the West, which uses sanctions to challenge normal economic competition.

45 Pravitelstvo Rossiiskoi Federatsii, Energeticheskaya strategiya Rossii na period do 2030 goda.

46 'Report by Alexey Miller, Chairman of the Gazprom Management Committee at the Annual General Shareholders Meeting', Gazprom, 30 June 2017, www.gazprom.ru/press/news/miller-journal/ $2017 / 340087 /$.

47 Ministry of Energy, Proekt enoergostrategii Rossiiskoi Federatsii na period do 2035 goda.

48 See, for example, 'Igor Sechin Made a Keynote Speech at the 4th Eurasian Forum in Verona', Rosneft, 22 October 2015, www.rosneft.ru/press/today/item/176755/. 
Among companies, Rosneft and Gazprom remain the biggest proponents of diversification. They demonstrate their commitment via the construction of pipelines and by increasing their exports to the AsiaPacific region (APR). Rosneft, in particular, declared in late 2018 that Asian markets were more important than European ones (48 per cent vs 40 per cent). ${ }^{49}$ Novatek began supplying LNG to China via the Northern Sea Route in 2018, reducing the duration of delivery from 35 to 19 days and thereby increasing its attractiveness. It is clear that Russian companies support diversification; however, any increase in the supply of Russian LNG, not to mention the construction of gas pipelines, will predictably increase the salience of debates about the inefficiency of coordination of Russian export strategies in hydrocarbons.

Surprisingly, there is consensus among experts about the need for diversification from Europe to Asia. One line of debate is about whether this diversification is real. Some believe that geographical diversification proceeds with normal speed as it should; however, others maintain that it is slow and is more declaratory than real. ${ }^{50}$ Some experts point out that, despite official recognition that traditional markets are less and less significant, export infrastructure in that direction is still bolstered (e.g. Nord Stream, South/Turkish Stream) and existing capacities exceed what is needed to meet current obligations (i.e. ground and sea transportation). Consequently, in that sense, the 2019 ESD is seen as offering rhetorical change only.

Another line of expert discussion is about the economic salience of diversification. Observing price dynamics, some experts argue that Asian markets are becoming increasingly attractive compared to European ones. Previous conclusions about the higher profitability of European markets have been challenged on a number of grounds, including competition in European markets as a result of liberalisation, limits on long-term contracts with oil indexation, inflows of LNG, and increased demand in Asian markets. ${ }^{51}$ On the last point, studies stress favourable gas price dynamics

49 V. Petlevoy, 'Osnovnym exportnym rynkom dlya 'Rosnefti' vmesto Evropy stala Aziya [Asia has become the main export market for Rosneft instead of Europe], Vedomosti, 7 November 2018, www. vedomosti.ru/business/articles/2018/11/07/785822-rosnefti-vmesto-evropi-stala-aziya.

50 M. Korchemkin, 'Rossiiskii Neftegaz', Facebook Group, 14 May 2019, www.facebook.com/ groups/437496816287290/?ref=bookmarks.

51 Kornilov and Tanurkov cf. Petlevoy, 'Osnovnym exportnym rynkom dlya 'Rosnefti' vmesto Evropy stala Aziya'. 
in Asia. ${ }^{52}$ Yet, the durability of this remains a contested issue. At the same time, some experts highlight the political rationale of cooperation with Asian countries (in particular China). ${ }^{53}$

In sum, although the 2019 ESD maintains the need to diversify export markets from Europe to Asia, its nuances are different from earlier documents. First, the doctrine does not mention European markets. Second, the economic rationale for diversification towards Asia is not only stressed but also reinforced by experts. While companies continue their penetration into Asian markets, experts debate whether the proclaimed goal of diversification and its implementation is real or merely declaratory.

\section{Conclusion}

Although the 2019 ESD is presented as a response to a radically new global situation and Russia's position in it, the three groups of issues reviewed above show much more continuity than change. The ambiguity between geopolitics and market economics has been maintained, although the shift to geopolitics and closer state involvement has been strengthened. In that sense, Russia has regained its traditional course. Similarly, the diversification of markets from Europe to Asia has been maintained.

Yet, at the same time, subtle differences can also be discerned. Geopolitics is driven by the sense of external threats (including sanctions) and internal dangers. While the influence of the Russian state in the energy sector has increased, the key reason, according to the official discourse, is unfair competition from the West in the form of sanctions. Whereas before 2014, Russia talked about discrimination on political grounds, the present rhetoric stresses economic reasoning. Economic justifications (rather than political ones) are also used to justify diversification to Asia.

The most noticeable change in the 2019 policy debates concerns energy mix. Without fully embracing energy transition, the 2019 ESD recognises green energy, energy efficiency and climate change as challenges.

52 A. Sobko, 'Gaz desheveet, potomu chto neft dorozhaet: nachalas novaya epoha' [Gas is getting cheaper because oil is getting more expensive: A new era has begun], RIA, 4 July 2019, ria.ru/2019 0704/1556152605.html.

53 A. A. Makarov, T. A. Mitrova and V. A. Kulagin, Global and Russian Energy Outlook 2019. 
And, although its policy choices remain unchanged, a certain degree of novelty stems from its very recognition of green energy and its influence on Russia's export of hydrocarbons.

The three groups of issues examined-market economics vs geopolitics, the energy mix and geographical diversification-are interrelated. Whereby, geopolitics constrains the development of clean energy and renewables, which directs the diversification of markets, and geographical diversification results in gains that become more salient as a result of the EU's policy choices on green energy. The issue that causes the most debate in Russia today is energy mix. Here the views are polarised between those that profess the inevitability of the energy transition and the need for Russia to adopt it, and those who still believe that traditional resources will maintain their centrality because renewables (and climate change) are an expensive political choice. Discussion about geopolitics vs market economics are largely missing in such debates. Where they exist, they involve experts who insist on the need for a true market, companies that insist on export competition and others who are happy with the status quo. Debates about geographical diversification tend to focus on whether it is actually happening and the extent to which it is economically justified.

The evolution from political to economic reasoning is noticeable in Russian discourses about energy. It is visible in debates about geopolitics vs market economics, in discussions about energy mix and in questions over the motivation for geographical diversification from Europe to Asia. In sum, Russian debates reveal a wide variety of opinions, which is healthy for policy debates. However, the extent to which this variation affects policymaking is unclear. Noticeably, while some believe that the ESD is a result of experts' deliberation, others insist that policy discussions have not been sufficient and a further set of studies is needed to verify the 2019 ESD's conclusions. ${ }^{54}$

54 Simonov, 'Voprosy k ispolnitelyam'. See also Chugunoff, 'Rossiiskii Neftegaz'. 
This text is taken from Russian Energy Strategy in the Asia-Pacific: Implications for Australia, edited by Elizabeth Buchanan, published 2021 by ANU Press, The Australian National University, Canberra, Australia.

doi.org/10.22459/RESAP.2021.09 